\title{
Narrativas biográficas: a construção da identidade espírita no Brasil e sua fragmentação
}

\author{
SANDRA JACQUELINE STOLL
}

\section{Introdução}

Para se designarem coisas novas são precisos termos novos [...] Os vocábulos espiritual, espiritualista, espiritualismo têm acepção bem definida [...] Com efeito, o espiritualismo é o oposto do materialismo. Quem quer que acredite haver alguma coisa em si além da matéria, é espiritualista. Não segue daí, porém, que creia na existência dos Espíritos ou em suas comunicações com o mundo visível [...] para indicar a crença a que vimos a referir-nos (empregaremos) os termos espírita ou Espiritismo. Diremos, pois, que a doutrina espírita ou o Espiritismo tem por princípio as relações do mundo material com os Espíritos ou seres do mundo invisível.

(Allan Kardec, O livro dos espíritos, 1860)

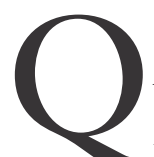

UASE 150 anos se passaram desde o lançamento do primeiro livro de Allan Kardec, que inaugura a difusão do Espiritismo na França e demais países da Europa ${ }^{1}$. Uma homenagem a seu autor teve lugar no mês de outubro último, a pretexto da comemoração dos duzentos anos de seu nascimento. Paris, sede do evento, ainda guarda a aura mítica de berço de origem da doutrina, embora na França, assim como na Europa de modo geral, Allan Kardec e sua doutrina sejam hoje praticamente desconhecidos. Além do número reduzido de seus adeptos, atesta-o a participação minoritária dos europeus na programação do evento ${ }^{2}$. Dentre os países participantes, o de maior destaque é o Brasil, sinalizando, de um lado, a posição por este assumida no contexto internacional como pólo de irradiação da doutrina e, de outro, a importância conquistada pelo Espiritismo no cenário religioso nacional.

Num momento em que a inserção na mídia, em especial a televisão, se destaca como fator de divulgação doutrinária, constituindo um novo campo de disputa no espaço público, o Espiritismo vem alargando sua inserção social, especialmente entre os segmentos da classe média, por meio do investimento no campo literário. "A literatura espírita é o mais novo fenômeno editorial do país", afirma uma reportagem da revista Época, de maio de 2003. "Tradicionalmente vendidos nos redutos kardecistas, os livros psicografados - escritos por pessoas que se dizem conectadas com almas que enviam mensagens do Além - (vêm despertando) a atenção das grandes editoras". É o caso da Editora Siciliano, uma 
das maiores do país, que lançou em meados de 2003 o seu primeiro livro espírita, Do outro lado da vida, de Arthur Vasconcelos: "sem divulgação, vendeu 10 mil exemplares em dois meses". A preferência do público por esse tipo de literatura é aquilatada como segue nesta mesma reportagem: "Hoje, um em cada dez clientes entra em livrarias para comprar livros que trazem ditames enviados por espíritos". Uma pesquisa realizada no site Submarino confirma essa tendência: “o leitor espírita responde por mais da metade das encomendas de livros religiosos e compra 15\% mais que os outros". Os campeões de venda nesse segmento são Allan Kardec, Chico Xavier, Zíbia Gasparetto ${ }^{3}$ e Vera Lúcia Marinzeck. No entanto, como observa o diretor-comercial do site Submarino, "pessoas de todas as crenças (consomem) esse tipo de obra", o que indica que a difusão dos preceitos doutrinários espíritas extrapola de longe suas fronteiras institucionais.

Algumas pesquisas de opinião pública corroboram essa conclusão, em especial quando se trata do tema da representação da vida pós-morte: uma delas, realizada em 1998 pelo Instituto Gallup, constatou que 45,9\%, ou seja, quase metade dos católicos que dizem freqüentar semanalmente serviços religiosos afirma "acreditar na reencarnação". Embora se trate de tema proscrito pela tradição cristã, o mesmo constatou o Ceris (Centro de Estatística Religiosa e Investigações Sociais) numa pesquisa realizada em 2000 em cinco metrópoles brasileiras: $55,7 \%$ dos entrevistados disseram "acreditar em vida após a morte", sendo que $35,8 \%$ destes afirmaram crer na "reencarnação dos mortos" 4 .

Para se aquilatar a profundidade cultural e a extensão social da difusão deste sistema de crenças, os dados dos censos demográficos são insuficientes, uma vez que estes são incapazes de apreender a "dupla pertença", fenômeno corrente no campo religioso brasileiro. Declarar-se "católico" é uma prática ainda vigente entre os espíritas, assim como se dizer "espírita" é uma prática dos adeptos de religiões afro-brasileiras, especialmente entre os segmentos sociais de baixa renda ${ }^{5}$. Herdada dos tempos da perseguição policial às atividades mediúnicas de cura, sob o respaldo da Constituição de 1891, esta prática contribui, juntamente com a "transitividade" (espécie de religiosidade itinerante, cujos registros parecem ter-se acentuado nos últimos anos) ao delineamento de "um cenário em que a religiosidade é vivida de maneira mais alargada do que aquela confessada ao entrevistador" (Almeida, 2004, p. 11). Neste cenário se incluem não apenas os que "se dizem católicos" mas professam crenças espíritas (ou outras), como também aqueles que se declaram "sem religião". Conforme sugere Almeida (2004), este tipo de declaração não significa necessariamente "ausência de religiosidade". Segundo o autor, esta categoria abriga pessoas que "não têm freqüência assídua aos serviços religiosos, nem envolvimentos pessoais com a comunidade moral [...], mas mantém uma disposição religiosa frente ao mundo, principalmente em situações de insegurança física, emocional, financeira etc.” (Almeida, 2004, p. 7). Dentre estes também se incluem aqueles que inventam o seu próprio "cardápio de credos e práticas”, desvinculando-se, dessa forma, de marcas de pertencimento definidas. 
A profusão contemporânea dessas territorialidades religiosas pouco institucionalizadas define uma nova configuração do campo religioso, na qual o Espiritismo encontra novos espaços sociais de difusão, pouco mensuráveis, no entanto, estatisticamente. As dificuldades de sua apreensão se refletem nos estudos mais recentes sobre a religiosidade brasileira contemporânea: freqüentemente estes se voltam para a análise da expansão dos evangélicos, com destaque para o "fenômeno da Igreja Universal" e a "guerra santa" que envolve suas relações com as religiões de tradição africana. Outro tema recorrente é a investida “carismática católica”, que também remete à questão da expansão pentecostal (Birman, 1994 e 1995; Mariz e Machado, 1994; Sanchis, 1994 e 2001; Almeida, 2003 dentre outros). Este artigo pretende contribuir para a complementação desse quadro, deslocando o foco de atenção para uma outra malha de relações consolidadas e em processo de elaboração no campo religioso brasileiro, na qual o Espiritismo figura como ponto de articulação.

\section{"Olhar de fora", "visão de dentro": versões da identidade espírita}

A experiência do transe, da possessão e da mediunidade tem sido largamente referenciada nos estudos antropológicos como denominador comum da religiosidade brasileira. Cândido Procópio Camargo (1961) foi o primeiro a pensar essa experiência em termos de um continuum, no qual o Espiritismo representaria uma estrutura "de mediação" entre tradições religiosas de origem afro ${ }^{6}$. Nas suas palavras:

pode-se perceber uma curva de modificações (nas práticas dos) terreiros, que permite ordenar os vários tipos em uma seqüência significativa - o continuum. O princípio teórico que preside a organização desse "gradiente" é a doutrina espírita: tanto mais "afro" será considerado o "terreiro" de umbanda quanto mais distante do centro do continuum; por sua vez, quanto mais próximo do kardecismo, diminui a riqueza ritualística e a ênfase em práticas mágicas, em virtude de uma "maior ênfase na interiorização da experiência religiosa, no aprendizado doutrinário e na vida moral” (Camargo, 1961. Cf. pp. 49 e 51).

Passados mais de trinta anos, Patrícia Birman retoma essa idéia, questionando a tendência que se tornou corrente na literatura antropológica: "Estamos, afinal, lidando com "religiões" autônomas, cada qual com sua "visão de mundo", ritos e mitos, ou estamos nos referindo a um universo de cultos inter-relacionados e subordinados à lógica associada à possessão?”. Questão que se desdobra em outra: "Será, de fato, que as identidades diferenciadas que se apresentam entre os cultos de possessão possuem um tal grau de autonomia que desencoraja qualquer tentativa de percebê-las integradas entre si, hierarquizadas (conforme) a visão dos religiosos?” (Birman, 1995, p. 13).

$\mathrm{O}$ trânsito dos adeptos entre as várias práticas religiosas associadas à possessão, como no caso de Cândido Procópio, leva a autora a explorar essa pista. 
Os próprios adeptos, assim como a maioria dos estudiosos do tema, no entanto, criticam essa postura. Dentre os primeiros, conforme salienta Cândido Procópio, os espíritas são os mais radicais na rejeição dessa hipótese. Segundo o autor, eles se dividem entre aqueles que repelem "formalmente qualquer semelhança com a Umbanda, alegando que a mediunidade não é traço característico de nenhuma religião em especial", enquanto outros argumentam ser a Umbanda uma "modalidade de crença adequada aos espíritos mais ignorantes", portanto, "hierarquicamente inferior"(Camargo, 1961, pp. 86 e 87)7. Os umbandistas, por sua vez, incorporam a representação hierárquica como modo de afirmação da diferença, uma vez que atribuem "superioridade moral e 'evolutiva' ao sistema de Kardec" (Camargo, 1961, p. 86).

Quanto aos autores que se dedicaram ao estudo desse tema, a tendência dominante consiste na construção dessas identidades religiosas em termos de confronto, de oposição. Contrapondo-se às religiões de tradição africana, o Espiritismo é apresentado como uma espécie de "espelho invertido", seja quanto a suas características sociais e étnicas, seja quanto à estrutura ritual e doutrinária. Essa tradição, inaugurada por Bastide (1960), foi perpetuada pelos trabalhos que se seguiram (Ortiz, 1978; Maggie, 1982; Brown, 1985; Cavalcanti, 1983, dentre outros).

O recorte proposto por essas abordagens, centrado no fenômeno da possessão, deixa de lado, ou pelo menos coloca em segundo plano, uma outra dimensão das relações construídas pelo Espiritismo no campo religioso. Refiro-me às relações estabelecidas com o Catolicismo, a religião ainda hoje hegemônica no país. Minimizada pela literatura, essa dimensão é de fundamental importância para se compreender como se constituiu a identidade espírita na Brasil. Como pretendo demonstrar adiante, no contexto das disputas e negociações com o Catolicismo é que se forja a inserção do Espiritismo no campo religioso brasileiro, definindo-se a partir desta relação o seu ethos marcadamente católico - sinal diacrítico que define o seu perfil em oposição ao modelo "científico", tido como "versão original", vinda da França. Desenvolvo esse tema a partir de dois estudos de caso: o primeiro, tem como objeto a história de vida e carreira de Chico Xavier; o segundo trata da trajetória recente do médium Luiz Antonio Gasparetto. O Catolicismo ocupa na trajetória de ambos lugar central: no caso do primeiro, como matriz de reinterpretação da doutrina espírita; no segundo, como alvo de crítica, em função da qual se busca a construção de relações com novos interlocutores, em especial com o universo da chamada "Nova Era" . A escolha dessas duas biografias se justifica por razões metodológicas: concebidas como figuras paradigmáticas, esses personagens representam momentos distintos da história do Espiritismo no Brasil. Ao mesmo tempo, a convivência dos modelos de espiritualidade por eles engendrados evidencia modos concorrentes da expressão contemporânea do Espiritismo no país. A apresentação destes personagens segue a cronologia, assim como uma certa "hierarquia espiritual": começo pelo mais famoso dentre eles. 


\section{Chico Xavier, o "homem-santo"}

É possível duvidar do Espiritismo, mas é impossível duvidar de Francisco Cândido Xavier [...] Os que a ele chegam, carregados das aflições do mundo, saem com o coração leve, a fé reanimada [...] Ninguém pode vê-lo como impostor. A menos que a impostura pudesse ser também astuta forma de santidade.

(Bacelli, Chico Xavier: mediunidade e coração)

Para milhões de brasileiros o médium mineiro é um santo, a ponte mais confiável até o outro mundo, a prova de que a morte não existe. Para outros tantos é um personagem exótico. (Apesar de) menosprezado pela intelligentsia nacional [...] sobreviveu. Virou mito.

(Souto Maior, As vidas de Chico Xavier)

Os espíritas de todo o mundo acreditam numa futura missão civilizadora do Brasil [...] Se assim for, Chico Xavier terá sido, sem dúvida, o grande apóstolo da Nova Era. (Ubiratan Machado, Uma vida com amor)

A liderança de Chico Xavier no meio espírita se consolidou em torno dos anos de 1940 e 1950, pouco mais de meio século depois da constituição dos primeiros grupos responsáveis pela difusão da doutrina no país. Até então raros eram os nomes de destaque nesse universo religioso oriundos das classes populares. Chico Xavier constitui uma exceção. Mas sua importância, como sugerem as frases acima, extravasa esse detalhe. Como pretendo demonstrar a seguir, a imagem de "homem-santo" não traduz uma apropriação indébita. Ao contrário, reflete o processo cultural de inserção do Espiritismo no campo religioso brasileiro por meio de um diálogo intenso, muitas vezes conflituoso, com a religião dominante no país: o Catolicismo. Apreenderemos as bases dessa construção a partir da narrativa de sua história de vida e carreira religiosa.

\section{Memória da mediunidade}

Chico Xavier ficou conhecido como um bom contador de histórias. De sua vida ele contou várias, registradas mais tarde em livros, por terceiros. Sem fazer muita conta do "cenário", os "casos" relatados descrevem em flashes rápidos experiências da infância, da família, do trabalho e, sobretudo, da mediunidade. Retratos soltos que permitiriam múltiplas composições. Alinhavados, porém,à semelhança da história de vida dos santos, por meio deles se exalta, sobretudo, as qualidades morais do personagem, numa clara intenção de produzir um modelo de exemplaridade.

O "itinerário da santidade", tal como o concebe Michel de Certeau (1982) serve como parâmetro para se apreender a estrutura dessa narrativa. Segundo o autor, esse tipo de percurso compreende dois movimentos: primeiro o indivíduo “assume distância com relação às origens [...] A vocação do santo o exila da 
cidade para conduzi-lo ao deserto, aos campos ou a terras longínquas"; o segundo movimento consiste no "itinerário de retorno". Do "lugar sagrado" o indivíduo retorna ao grupo ou comunidade de origem ou, então, simplesmente volta à vida na cidade ou percorre múltiplas cidades (cf. pp. 269 e 277). O primeiro movimento delimita o "tempo de ascese"; o segundo, de retorno, "o tempo dos milagres e das conversões” (p. 277). Essas duas etapas conformam o quadro "inicial" e "final" do "itinerário da santidade". Em meio a elas situa-se o período das "provações”, instância ritual que dinamiza o esquema, permitindo particularizar, personalizar "a história".

A narrativa da vida de Chico Xavier, como se verá em seguida, exige uma adaptação desse modelo, visto que a fase profana de sua vida, isto é, o período que antecede sua conversão ao Espiritismo, incorpora o início das "provações". Relida como uma história de eleição, a narrativa de sua vida tem como fio condutor o "sofrimento", categoria por meio da qual se tece e se entrelaçam as experiências da infância aos percalços do trabalho mediúnico, aos quais o passar do tempo acrescenta o desgaste físico, os problemas de saúde e as vicissitudes da velhice. Trata-se, portanto, de uma única e mesma imagem, sempre renovada, que como categoria narrativa permite estabelecer laços de continuidade entre as etapas fundamentais de sua carreira religiosa e trajetória pessoal.

O modelo hagiográfico informa essa moldura narrativa, o que se pode observar tanto nas suas etapas fundamentais, como nos temas a que estas remetem. A intenção do que segue é salientar a inspiração dessa construção narrativa no modelo de "virtudes cristãs", tal como formulado pelo Catolicismo.

\section{Reunindo fragmentos}

\section{“Com o diabo no corpo": a visão católica do fenômeno mediúnico}

Nascido em 2 de abril de 1910, numa pequena cidade mineira do interior, Chico Xavier teve uma infância bastante atribulada. Filho mais velho de uma extensa prole de um casal de poucas posses, sua educação, como era tradição do lugar, foi lastreada no Catolicismo. Nesta fase, no entanto, segundo seus relatos, ocorrem as primeiras manifestações de "contato com os espíritos", tendo como evento propulsor a morte de sua mãe, ocorrida em 1915, quando ele tinha apenas cinco anos de idade. João Cândido, o pai, era vendedor de bilhetes de loteria e viajava muito. Sem condições de criar os filhos sozinho, resolveu distribuí-los entre parentes e vizinhos. Chico Xavier foi entregue a Rita de Cássia, sua madrinha. A memória desse tempo é de maus tratos: ela o surrava com vara de marmelo todos os dias. Muitas vezes sem motivo. Os castigos, porém, aumentaram depois que ele contou-lhe ter visto e conversado com a mãe no fundo do quintal. A partir daí, além da surras, a madrinha passou a dar-lhe garfadas na barriga, acusando-o, em função de suas "conversas com os mortos", de "ter parte com o diabo". Esse suplício durou dois anos. Depois disso ele voltou a morar com o pai, que se casara novamente. 
As "visões", porém, não cessaram, o que lhe causou inúmeros conflitos dentro e fora do contexto familiar. Segundo se conta, Chico "levantava no meio da noite, batia papo com fantasmas e muitas vezes estragava o café da manhã do pai com notícias de parentes mortos” (Souto Maior, 1994, p. 16). Cidália, sua madrasta, com quem ele conversava nos fins de tarde ao pé do tanque, por inúmeras vezes ouviu-o dizer que "via próximas ao varal figuras cobertas com mantos coloridos" (Souto Maior, 1994, p. 17). Esta, segundo se conta, dava-lhe crédito, ao contrário de D. Rosária, sua professora primária. Ao participar de um concurso de redação instituído pelo governo do Estado de Minas Gerais em comemoração ao primeiro centenário da Independência, Chico levantou-se em meio à prova para comunicar à professora que pressentia a presença de um homem que lhe ditava um texto. Sem dar-lhe muita atenção, ela pediu que ele voltasse ao seu lugar e terminasse a prova. A notícia, porém, espalhou-se na sala e na aula seguinte os colegas fizeram-lhe um desafio. Como prova queriam que o "tal homem" viesse "outra vez, ali mesmo [...] à frente de todos para escrever sobre um tema escolhido por eles". O tema proposto, escolhido ao acaso por um dos meninos, foi o grão de areia. Chico relata: "lembro-me que o espírito [...] ao meu lado começou ditando: "Meus filhos, que ninguém escarneça da criação. O grão de areia é quase nada, mas parece uma estrela" (Barbosa, [1967]1992, p. 17).

Fatos como esses se repetiam quase diariamente, em sonhos, na escola, nos momentos de ócio. João Cândido inúmeras vezes ameaçou internar o filho num sanatório. A tese de que se tratava de caso de loucura era, porém, refutada pelo padre Scarzelli, que procurava aplacar a situação com o receituário católico tradicional: novenas, penitências, rezar mil Ave-Marias... Chico Xavier lembra, por exemplo, que aos nove anos de idade, por ordem do pároco, participou de uma procissão carregando uma pedra de quinze quilos na cabeça. Penitência complementada pela obrigação de repetir mil vezes a Ave-Maria. Além disso, impuseram-lhe que freqüentasse regularmente a Igreja, participando inclusive das novenas. Os resultados, segundo ele, não foram os esperados: enquanto rezava e contava acompanhando a procissão, "um espírito desocupado fazia caretas e bocas para atrapalhar seus cálculos”. Além disso, quando estava na Igreja, cumprindo as novenas, "assombrações flutuavam sobre os bancos e beijavam os santos" (Souto Maior, 1994, p. 11) Padre Scarzelli decidiu então "ser mais duro". Aconselhou João Cândido, pai de Chico, a ocupar o tempo livre do menino, arranjando-lhe um emprego. À época, a fábrica de tecidos da cidade estava empregando crianças para trabalhar no período noturno. Chico Xavier foi admitido:

Fui trabalhar como tecelão. Entrava às três da tarde, saía à uma da madrugada. Dormia até às seis, ia para a escola, saía às onze. Almoçava, dormia uma hora [...] e entrava de novo na fábrica (Machado, 1984 [1992], pp. 25-26).

A rotina diária era estafante para uma criança de dez anos; restava-lhe apenas o fim de semana para descanso e lazer. Algumas atividades, contudo, foramlhe proibidas: o padre Scarzelli recomendou, como medida complementar, que 
se evitasse a "má influência" dos livros, revistas e jornais. Assentindo, João Cândido "fez uma fogueira das páginas proibidas" (Machado, 1984[1992], p. 18). Inconformado, Chico relata que recorreu, como sempre fazia, ao "espírito" da mãe. Esta lhe deu um conselho:

Aprenda a calar-se. Quando lembrar, por exemplo, alguma lição ou experiência recebida em sonho, fique em silêncio. Mais tarde talvez você possa falar (Machado, 1984 [1992], p. 18).

Chico passou então a restringir seus comentários ao confessionário. Mas o padre Scarzelli insistia: "Ninguém volta a conversar depois da morte". E acrescentava: "O demônio procura perturbar-lhe o caminho". Chico, porém, não se deixava convencer: "Mas padre, foi minha mãe quem veio [...]". O padre retrucava: "Foi o demônio [...]" (Machado, 1984 [1992], p. 18).

Há vários outros exemplos dessa mesma ordem, mas os enunciados me parecem suficientes para evidenciar o peso e o significado da interpretação institucional, católica do fenômeno mediúnico. A convergência de leigos e eclesiásticos na interpretação do fenômeno mediúnico chama atenção, considerando-se que o pároco e a madrinha de Chico Xavier o entendem da mesma forma, isto é, como "coisa do diabo". Essa convergência se manifesta também quanto às atitudes assumidas com relação ao fenômeno da mediunidade: ambos entendiam ser preciso reprimi-lo, inibir sua manifestação, num caso, por meio de castigos corporais, noutro, pela oração e penitência.

Confrontando-se na sua experiência cotidiana com esse caráter prescritivo do Catolicismo oficial em relação ao fenômeno da mediunidade, Chico Xavier desenvolveu uma relação ambígua com o Catolicismo: como se depreende dos exemplos acima, a experiência vivida coloca-o em confronto com os dogmas institucionais; ao mesmo tempo, na busca de um modelo de relação com os "espíritos" se aproxima de idéias e práticas correntes nos meios populares, em particular, aquelas que dizem respeito à relação com os santos.

\section{A conversão}

Transição de natureza marcadamente simbólica, a conversão de Chico Xavier ao Espiritismo ocorreu quando ele tinha dezessete anos, depois de assistir a uma sessão espírita a que foi submetida uma sua irmã, depois de anos de tratamentos médicos mal sucedidos na tentativa de controlar seus "acessos de loucura". Chico participou das orações e passes, sendo em seguida introduzido à obra de Allan Kardec.

A narrativa desse fato ao pároco e a decisão de seguir a nova doutrina marcam o seu desligamento oficial do Catolicismo. A mudança de tutoria constitui uma das marcas fundamentais do trânsito religioso, por meio do qual se inaugura a primeira fase do "itinerário da santidade", sinalizada pela ruptura com o universo de crença de origem. A tutela espiritual de Chico Xavier vinha sendo até então exercida pela mãe, "em espírito", e pelo padre. Essa dualidade é 
eliminada com a conversão religiosa, estabelecendo-se a partir daí a sujeição exclusiva à tutela dos "espíritos". Ritualmente, a mudança foi marcada pela substituição do vínculo de consangüinidade (mãe-filho) pelo vínculo de parentesco simbólico, selado na relação de apadrinhamento estabelecida entre médium e "guia-espiritual".

Uma fase liminar, característica dos processos iniciáticos, tem lugar nesse momento, caracterizada pela produção anônima de textos psicografados, os quais envolvem dupla iniciação: além do desenvolvimento da escrita mediúnica, estas promoveram a familiarização de Chico Xavier com um “discurso de virtudes”, que incisivamente remetia à questão da obediência, da paciência e da humildade. Esses temas, que até então haviam sido objeto de orientação materna como solução para os conflitos familiares, passaram, a partir de então, a servir de modelo para seu comportamento público.

O primeiro "encontro" com seu "guia-espiritual", ocorrido em 1931, promoveu o selamento de um "contrato de trabalho" entre ambos visando à produção de livros mediúnicos. Chico Xavier conta que se encontrava num final de tarde em orações à beira de um açude, localizado à saída da cidade, quando avistou um espírito "envergando uma túnica semelhante à dos sacerdotes" que a ele se apresentou: "Está disposto a trabalhar na mediunidade?", perguntou. "O senhor acha que estou em condições de aceitar o compromisso?", retrucou o médium. O "espírito" respondeu: "Perfeitamente, desde que respeite três pontos básicos". Enumerando-os, repetiu três vezes a palavra "disciplina” (Gama, [1955] 1992, p. 64).

A partir daí desenvolveu-se entre ambos uma relação duradoura, cotidiana, de caráter, sobretudo, disciplinador. O processo de sujeição à vontade "dos espíritos” não se deu sem resistência. Acabou, porém, se concretizando, por meio de um processo que envolveu a combinação de gestos de ruptura, assim como de continuidade em relação à filiação religiosa de origem. A relação médium/ "guia-espiritual" constitui uma relação de ordem ritual, que, a exemplo do que ocorre na relação com os santos, extravasa para a vida cotidiana, caracterizando-se em larga medida pela intimidade da relação de tipo filial. Por outro lado, a autoridade do "espírito-guia" se impõe nesse caso com base no modelo institucional católico. O preceito hierárquico da obediência, pilar dessa relação, se expressa, conforme relata Chico Xavier, de forma clara: "Emmanuel” se apresenta com vestes sacerdotais, semelhantes às de um padre jesuíta". Os trajes que ele ostenta (uma espécie de batina preta), assim como a rígida disciplina de trabalho e de vida imposta ao médium, remetem a práticas de ordem institucional.

Caracteriza, portanto, essa primeira etapa do percurso iniciático de Chico Xavier um duplo sincretismo com a tradição católica. Na etapa seguinte, "de retorno" a influência do modelo monástico católico se torna dominante, constituindo o meio pelo qual se produz a sua imagem pública. Sintetiza essa etapa a idéia de uma "vida desapropriada", expressão que desloca a idéia da santidade 
como algo socialmente construído, de modo a permitir a sua representação como uma epifania: em lugar da mudança, da evolução, o relato biográfico descreve uma "constância", postulando um "princípio gerador" do texto e suas manifestações de superfície [...] O fim repete o começo [...] tudo é dado na origem como "vocação" (ou) uma "eleição". Essa é "a lei que organiza a vida de santo" (Certeau, 1982, p. 273).

\section{A produção da exemplaridade}

Como se observa nos relatos hagiográficos, a construção de uma vida santificada é um projeto que se desenvolve ao longo de uma vida. De início, freqüientemente envolve hesitações, incertezas, dificuldades. Como ideal de comportamento, implica o endosso de um "modelo de virtudes", que deve se expressar por meio de provas públicas.

A bumildade, imposta na fase de disciplinamento, constitui um aspecto da vida de santo partilhado por vários sistemas de crença. A renúncia complementa esse modelo, podendo realizar-se por meio do retiro da sociedade ou pela criação de um estilo de vida sui generis, que se expressa pela oposição a valores culturais e/ ou sociais do meio envolvente, como ocorre nesse caso. Os relatos de Chico Xavier evidenciam que, para essa construção, inspirou-se no modelo monástico de virtuosidade católica, no qual constitui preceito fundamental a renúncia ao sexo, ao casamento e a bens materiais:

Para que os livros nascessem de minhas pobres faculdades, de modo mais intenso $[\ldots]$ foi preciso $[. .$.$] que eu aceitasse a existência em que me encontro,$ na qual o matrimônio [...] não seria possível. Isto não quer dizer que a mediunidade crie antagonismos entre médium e casamento terrestre, mas sim que determinadas tarefas mediúnicas requisitam condições especiais para que se façam cumpridas (Folha Espirita, nov. 1976; transcrito por Nobre, 1996, p. $145)$.

A renúncia ao matrimônio como condição de realização plena da potencialidade mediúnica sugere a concepção cristã do sacerdócio. No depoimento de Chico Xavier, como no de outros médiuns ${ }^{10}$, observa-se que a "imposição" do celibato legitima a releitura da própria biografia como a história de uma eleição. Chico Xavier explicitou inúmeras vezes essa sua condição recorrendo a frases feitas: "De que vale um perfume preso a um frasco?". Ou então: "Porque ficar preso a uma mulher?" Fazendo uso dos mesmos argumentos de que se serve o clero católico, dizia: “minha família é a humanidade" (Souto Maior, 1994, p. 74).

Capitalizadas simbolicamente, as práticas do" celibato e da castidade adquiriram, no decorrer do tempo, um novo significado, transformando-se de componente da personalidade do médium em forma de expressão modelar da mediunidade espírita. Não sendo esta, porém, uma norma doutrinária, o que esse percurso sinaliza é a apropriação por Chico Xavier de práticas institucionais de construção da santidade católica. 


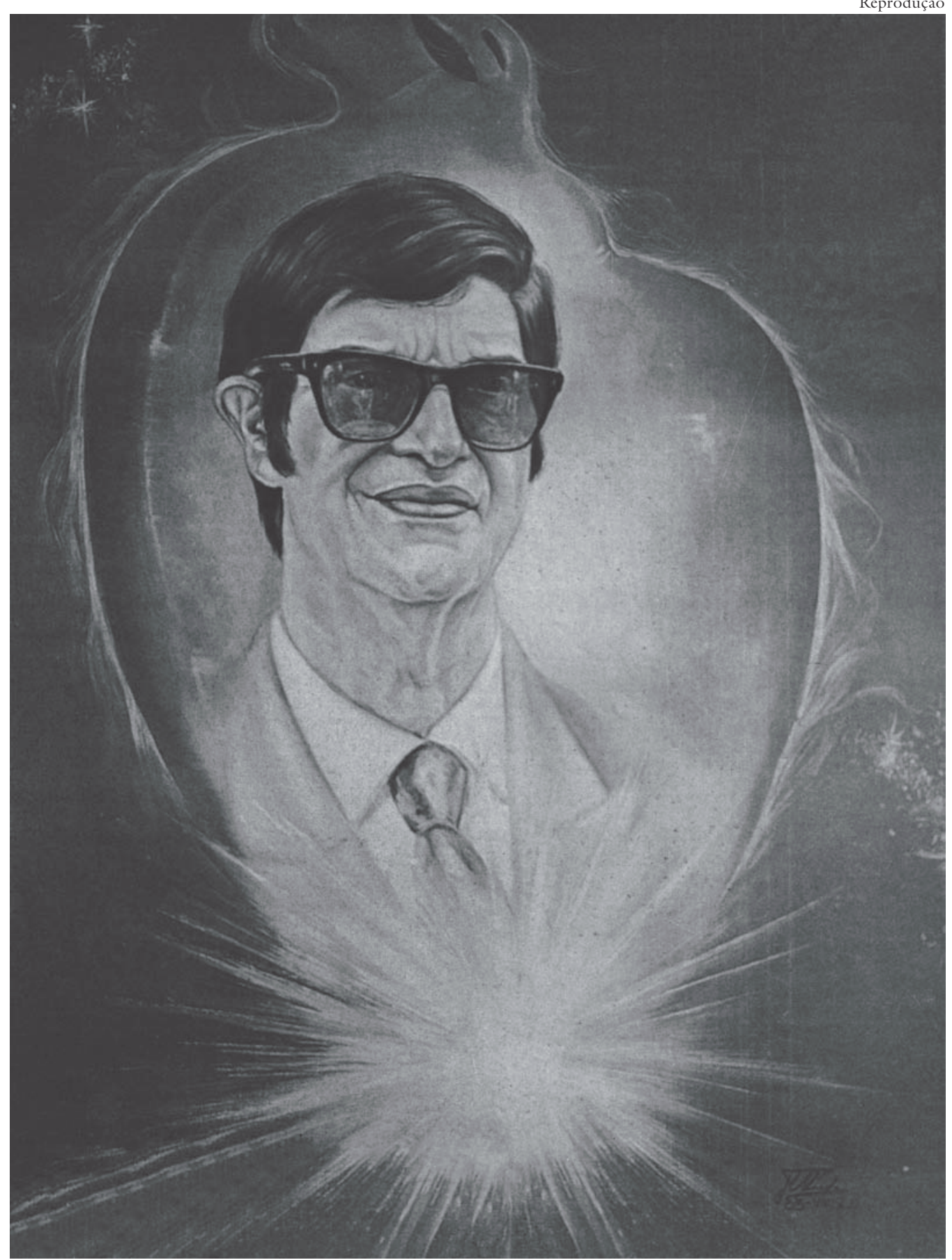

Desenbo de Chico Xavier.

O mesmo se observa no que se refere à relação com bens materiais. A experiência de pobreza veio-lhe de berço. Mas o desapego de bens materiais, como forma de sinalizar distanciamento das "coisas do mundo", foi uma experiência construída, referenciada no voto de pobreza católico. Dos relatos de Chico Xavier se depreende que este pouco desfrutou, em mais de noventa anos de existência, 
das benesses do chamado "mundo moderno". A princípio, em conseqüência das restrições financeiras que caracterizaram as condições de vida de sua família. Mais tarde, por opção pessoal: seus livros psicografados, traduzidos em várias línguas, renderam milhões em direitos autorais. Ele, contudo, nunca se apropriou de qualquer parcela desses rendimentos. Oficialmente, por meio de registro em cartório, doou os proventos dos livros mediúnicos às editoras de seus livros, bem como a inúmeras obras sociais. Viveu sempre exclusivamente de seu minguado salário de funcionário público de baixo escalão. Como prova de gratidão, muita gente chegou a lhe oferecer dinheiro. Chico recusava sistematicamente: "Ajude o primeiro necessitado que encontrar", dizia ele. O mesmo fazia com os presentes com que era agraciado. Sistematicamente recusou também doações que lhe foram feitas, envolvendo terras e dinheiro. Tudo foi repassado a instituições de caridade.

A prática da caridade, cujas formas introduzidas por Chico Xavier se tornaram mais tarde modelares para a prática espírita, também se inspira em práticas institucionais católicas. É o caso da peregrinação, denominação dada às visitas realizadas aos sábados à tarde a famílias que viviam embaixo de uma ponte em Pedro Leopoldo. Acompanhado de um grupo de amigos, Chico Xavier lhes levava doações feitas durante a semana em roupas e alimentos. Em Uberaba, onde ele se estabeleceu alguns anos mais tarde, essa atividade se estendeu aos bairros de periferia. As visitas a doentes em hospitais e a presidiários também foram incorporadas à sua prática, assim como a realização de caravanas pelos bairros de periferia à época do Natal para distribuição de presentes.

Do conjunto dessas práticas emerge a idéia de que a santidade como modo de vida se realiza como prática de doação. Fundamento da idéia de missão, este é um elemento-chave da ética cristã da santidade: enquanto os demais fazem e acumulam para si (ou para os seus), o santo é aquele que acumula gestos e práticas de doação aos outros. Esse ideal de vida pode realizar-se de formas variadas, segundo diferentes padrões culturais. Chico Xavier adotou o ethos católico, realizando-o de um modo particular.

Confundindo-se com a própria história do Espiritismo no Brasil, esse modelo por ele criado tornou-se hegemônico. O tributo a Chico Xavier se desdobra, portanto, entre vida e obra, uma construção mútua que garantiu a integração do Espiritismo ao ethos religioso nacional.

\section{Do Espiritismo à auto-ajuda}

No Brasil quase não faço mais (pintura mediúnica). Só realizo esse tipo de trabalho no exterior. As pinturas foram muito importantes na divulgação da mediunidade, principalmente nos Estados Unidos. Aqui já não há necessidade disso, existem muitos médiuns. Acabou a função. Continuo trabalhando com os espíritos, mas de outra maneira. É uma nova linha de espiritualização que estimula as pessoas a [...] usarem seu próprio poder.

(Gasparetto, Viva feliz, n. 1, jul. 1999) 
Três tendências, segundo D'Andrea (2000), sinalizam a dinâmica contemporânea no campo espírita: nos grupos de clientela predominantemente popular se observa a busca de novas sínteses com as religiões de tradição afro; os grupos com clientela majoritária entre as classes médias, por sua vez, tendem a se dividir entre a busca de alternativas mais seculares de expressão da doutrina, alinhandose, portanto, às chamadas paraciências, enquanto outros tendem à construção de novos diálogos no campo religioso, em especial com o chamado "complexo alternativo", "neo-esotérico" ou "Nova Era". A trajetória de Luiz Antonio Gasparetto ilustra essa última tendência: suas idéias e práticas mais recentes envolvem a combinação do exercício da mediunidade com práticas de auto-ajuda, tendo como tema fundamental a prosperidade.

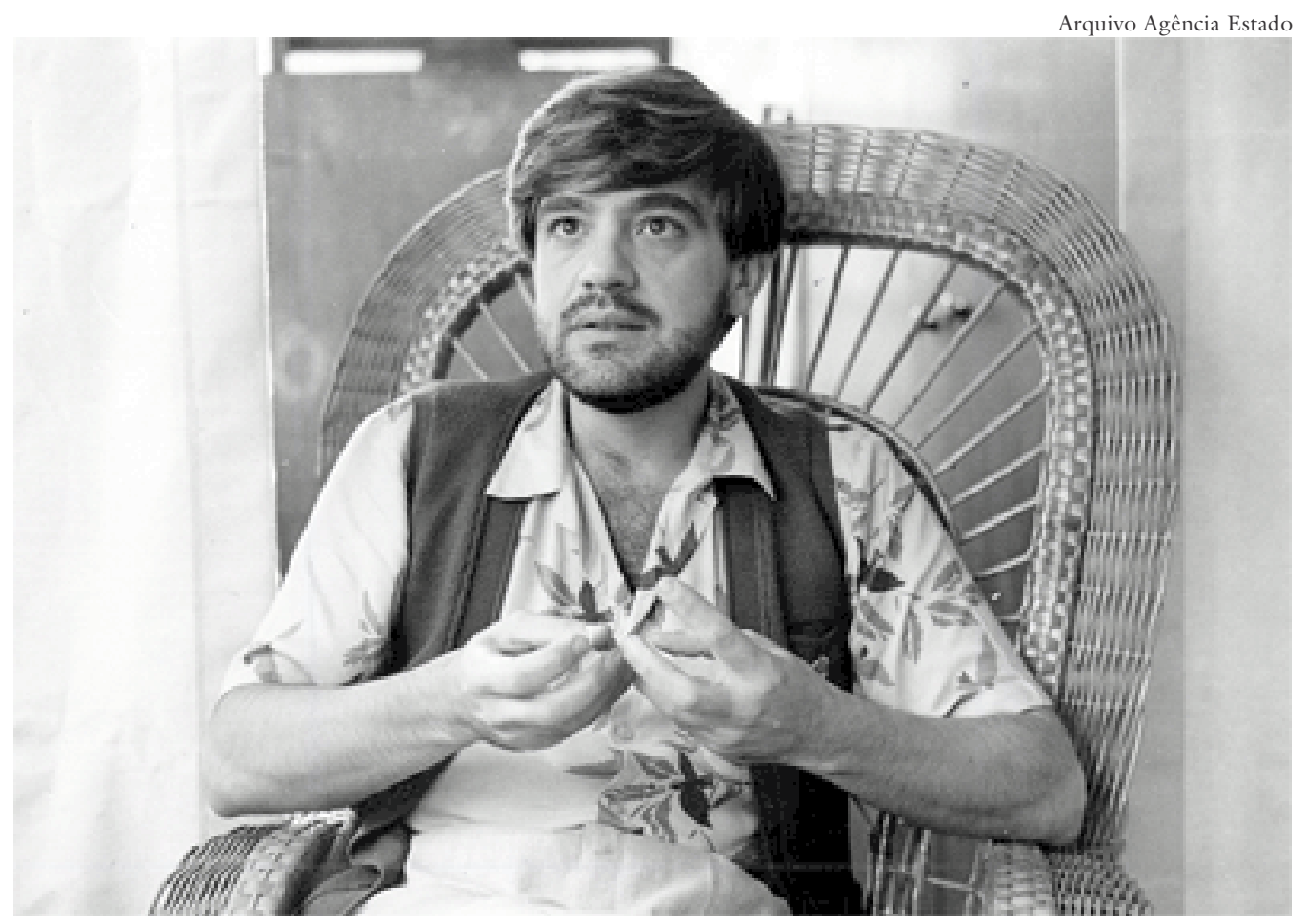

Luiz Antonio Gasparetto

\section{Trajetos}

Médium de formação espírita "tradicional", ele redefiniu o curso de sua trajetória religiosa nos anos de 1980. O marco inicial desse processo remonta à década anterior, período em que realizou uma série de viagens ao exterior, Europa e Estados Unidos especialmente. Estas lhe propiciaram dupla oportunidade: o contato com idéias e práticas de outros sistemas de conhecimento e a possibilidade de observação de outros valores e modos de se praticar a mediunidade. De volta ao Brasil, ele passou a manifestar publicamente suas críticas à prática da doutrina no país. O moralismo espírita constituía o principal alvo: sexo e dinheiro, segundo ele, constituem tabu no Brasil, o que ele atribui ao peso da tradição 
católica no país, bem como à origem católica dos primeiros médiuns. Segundo ele, "em sociedades liberais como os Estados Unidos, por exemplo", o mesmo não se observa:

Quando viajo para o estrangeiro e converso com os médiuns, os espíritos conversam abertamente de sexo e seus problemas. Aqui não. No Brasil nenhum espírito toca nesse assunto [...] Aqui só dizem: "vai tomar passe, vai tomar passe!”

Donde conclui:

apesar de os espíritos terem tentado passar uma mensagem libertadora, aqui os médiuns eram católicos e a linguagem que usaram era própria de sua estrutura mental. Passou o que foi possível. O resto ficou cheio de Catolicismo... ( $O$ assunto é... Espiritismo n. 21, s/d, p. 43).

Não apenas o aspecto moral, mas também suas práticas revelam uma postura conservadora: o movimento espírita, afirma Gasparetto, "é muito antiquado [...] não sai daquela caminhada, sempre igual: não muda o jeito do passe, não muda (a forma de) tratamento, não se conhece nada de energia [...]" (Planeta, 1990, p. 11). Críticas da mesma ordem são dirigidas às obras de Allan Kardec, as quais, segundo ele, são datadas: "o importante é sua postura. Quando digo que sou kardecista é por causa da pesquisa, do questionamento, da comparação, da busca e do método utilizado por Kardec [...] Agora, o conteúdo é coisa de época [...]" (Planeta, 1990 p. 11).

O descontentamento com a "tradição" levou-o, afinal, a conjugar dois caminhos trilhados a princípio de forma independente: a carreira profissional e o exercício da atividade mediúnica. Formado em psicologia e tendo freqüentado alguns cursos em Esalen (EUA), um dos centros mais famosos de irradiação das chamadas "terapias alternativas", ele acabou redefinindo o rumo de sua carreira:

Ao retornar ao Brasil, fazendo uso já dessa aprendizagem, minha vida mudou radicalmente: de um simples psicólogo de bairro, tornei-me professor de metafísica, ministrando cursos para [...] pessoas de vários países (Gasparetto, s/d, p. 9)

A criação do Espaço Vida e Consciência, nos anos de 1980, marca essa nova etapa. Distanciando-se da prática clínica convencional, suas atividades passaram a integrar o chamado circuito "neo-esotérico": promoção de cursos, palestras e workshops que tratam de questões relativas à espiritualidade, à saúde e a problemas que envolvem as relações cotidianas - afetivas, familiares e de trabalho.

De modo geral, essas atividades se desenvolvem em clima de espetáculo. Combinando técnicas de terapia com encenação, improvisação retórica e referências que remetem a uma espiritualidade difusa, seus cursos, palestras e shows não deixam de ter feições próprias. Engraçado, histriônico, Gasparetto é dono de uma extraordinária habilidade de comunicação e de sedução. Propositadamente, fala errado. Usa palavrões. Faz trejeitos, recorre ao sotaque ítalo-paulistano 
para construir "tipos", em geral personagens do universo cotidiano identificados com o seu público. Agressivo, por vezes sarcástico, cria situações de interpelação direta da platéia jogando com a ironia, a surpresa, o medo do ridículo. O ambiente, porém, é descontraído. Ri-se muito durante as suas palestras, cursos e shows à medida que se constroem, em geral por meio de diálogos imaginários, os estereótipos que retratam o público que o freqüenta: a "dona de casa", os "filhos", o "marido", a "sogra", a "vizinha", o "chefe", a "colega de trabalho" etc.

Por mais de dez anos essa atividade foi mantida como paralela àquela desenvolvida no "centro espírita", dirigido por sua família. Gradativamente, porém, as atividades deste último também começaram a ser modificadas. O distanciamento da "tradição" foi sinalizado de início pela mudança de sua denominação para Centro de Desenvolvimento Espiritual “Os Caminheiros”, mais adequada às práticas terapêuticas que passou a abrigar, que fogem ao repertório espírita, como o "passe com luzes" (prática que associa o passe espírita à cromoterapia) e sessões de "visualização criativa". Oriundas do universo das "terapias alternativas", essas técnicas introduzem na prática espírita a abordagem corporal de questões psicológicas. Novidades também foram introduzidas no campo "dos estudos": além das atividades tradicionais - ensino da doutrina e escola de "desenvolvimento mediúnico" -, passou-se a promover a atualização dos staff de voluntários por meio da promoção de palestras semanais. Realizadas por profissionais convidados, estas tratavam de temas que remetem ao universo "neo-esotérico": ufologia, astrologia, tarô, cristais etc. À clientela, por sua vez, também passaram a ser oferecidos cursos rápidos, em média de quatro semanas, voltados aos temas da auto-ajuda.

Alguns anos mais tarde essas mudanças foram complementadas pela transferência formal da direção do "centro" para Luiz Gasparetto. Ritualmente, o processo foi sinalizado pela mudança da tutela "da casa", cujo dirigente-espiritual passou a ser "Calunga", que se diz um preto-velho ${ }^{11}$. Figura que remete ao universo da umbanda, reza a norma ser este um personagem excluído do panteão espírita, já que são oriundos do meio "erudito" aqueles que figuram, de modo geral, como "guias espirituais" - pintores e escritores brasileiros e estrangeiros e, dentre os profissionais liberais, especialmente médicos.

A “mistura” do ideário e de práticas da auto-ajuda com uma personagem que tem por referência o universo mítico da umbanda resulta numa alternativa imprevista. Porém, não implica neste caso a adesão a prescrições rituais e doutrinárias desse sistema religioso. Embora sua "manifestação" seja marcada pela performance corporal e o linguajar típico desse personagem, "Calunga" constitui, na verdade, uma figura metafórica. Sua condição de outsider do panteão espírita serve à ritualização do afastamento da "tradição" espírita, autorizando, dessa forma, a incorporação de idéias e de práticas de outros sistemas simbólicos, seculares (como é o caso da "auto-ajuda") e/ou religiosos. 
O passo seguinte, envolvendo o fechamento do centro em 1995, marca o definitivo rompimento da família Gasparetto com a moral espírita, no que se refere ao exercício da mediunidade como prática de doação. Desde meados dos anos de 1980 os livros produzidos por Zíbia e Luiz Gasparetto passaram a ser editados por uma editora comercial, de propriedade da família, transferindo-se assim a sua renda das atividades filantrópicas para a apropriação pessoal dos direitos autorais. Uma década mais tarde, o mesmo se observa com relação à atuação de "Calunga": uma vez fechado o centro "Os Caminheiros", este passou a protagonizar cursos e palestras no Espaço Vida e Consciência, que como as demais atividades ali desenvolvidas se destinam a grandes platéias e são pagos. Consolida-se, assim, a passagem dessa corrente do Espiritismo da ética cristã aos valores cristalizados pela ética individualista da doutrina da prosperidade.

\section{Modos de crer}

A localização dos indivíduos como lugar de elaboração da crença, reiterada pela estratégia metodológica adotada, traz à tona a vitalidade do sincretismo como uma prática de inovação e/ou invenção de tradições. Sua racionalidade só pode ser apreendida localizadamente, uma vez que as possibilidades e os limites de comunicação e articulação entre sistemas diversos de crença não são dados em caráter universal. Os exemplos apresentados reiteram essa idéia, na medida em que contextualizam as alternativas apresentadas em diferentes momentos históricos. Alternativas essas construídas por meio de articulações diversas estabelecidas com os segmentos "popular" e "erudito" do campo religioso, resultando no estabelecimento de relações distintas com símbolos e segmentos da cultura religiosa brasileira.

\section{Notas}

1 A primeira edição d'O livro dos espíritosé de 1857. Em 1860, esse título foi relançado como edição revista e ampliada. As citações deste artigo se baseiam nesta última.

2 De acordo com Aubrée e Laplantine (1990) o movimento espírita na França se desagregou rapidamente após a morte de Allan Kardec. Acusações de fraude, as novas descobertas científicas e a multiplicação das dissensões no "meio espiritualista", às quais se soma a morte dos principais líderes da doutrina entre os anos de 1920-1930 são os principais fatores arrolados pelos autores como justificativa para o seu quase desaparecimento na França. Iniciativas recentes, realizadas por pequenos grupos, a partir dos anos de 1970-1980, em algumas cidades da França, Bélgica e Canadá são apontadas como focos de reorganização do movimento. Sobre este, tem-se notícias em publicações como Le Journal Spirite, de Nancy, assim como em publicações espíritas brasileiras, como a Folha Espirita. O papel do Brasil na promoção desse movimento de difusão do Espiritismo em países de língua francesa é objeto de reflexão de algumas matérias nesta última. A divulgação do evento em questão atesta a importância do Brasil nesse sentido: o Conselho Espírita Internacional, promotor das co- 
memorações dos duzentos anos de nascimento de Allan Kardec, tem sede em Brasília/ DF. Para outras informações sobre este œltimo veja-se www.spiritist.org

3 Há mais de dez anos presente na lista dos mais vendidos, Zíbia Gasparetto é considerada atualmente "a mais popular escritora mediúnica". Outras informações sobre sua produção literária podem ser obtidas na edição de maio de 2003 da revista Época.

4 Pesquisa publicada pela revista Veja, 2 abr. 1997. Este e outros dados do censo de 1991 foram analisados e comentados por Leandro Carneiro e Luiz Eduardo Soares, 1992. A pesquisa do Ceris (Centro de Estatística Religiosa e Investigações Sociais) mencionada se encontra em Desafios do Catolicismo na cidade. Pesquisa em regiões metropolitanas brasileiras. São Paulo, Paulus, 2002.

5 Os números subestimados dos Censos Demográficos já são assinalados pelos primeiros estudos sobre as religiões mediúnicas. Veja-se, por exemplo, com relação aos adeptos das religiões afro-brasileiras, Camargo, 1960 e para o período mais recente Almeida, 2004. Com relação ao Espiritismo, campanhas visando à declaração da adesão religiosa ao Espiritismo foram realizadas no œltimo censo (2000), como se pode verificar em artigos publicados na Folha Espirita e O Reformador.

6 Birman, 1995 sustenta a perspectiva do continuum tomando por referência o trânsito religioso dos adeptos e não as idéias, práticas e estrutura de organização religiosa, base da proposta de Cândido Procópio. Para a crítica deste último veja-se Goldman, 1985.

7 Análise mais recente desse tema é realizada por Giumbelli, 2003.

8 Os dados aqui apresentados se baseiam na minha tese de doutorado em Antropologia Social, defendida em 1999 na Universidade de São Paulo, intitulada Entre dois mundos: o Espiritismo da França e no Brasil, que foi publicada sob o título Espiritismo à Brasileira. Edusp/Orion, 2003.

9 Por meio da mediunidade de Chico Xavier, "Emmanuel" relata algumas de suas "encarnações”, iniciando a narrativa à época do Império Romano. Sua última “experiência terrena", segundo Chico Xavier, foi a "encarnação" como o jesuíta Manoel da Nóbrega, um dos fundadores da cidade de São Paulo". Veja-se a esse respeito Costa e Silva, 1995; Tavares, [1967]1991 e Machado, 1983, dentre outros.

10 Sobre esses relatos consulte-se Dantas, 1988; Rodrigues, 1987 e Prandi, 1996, dentre outros.

11 Num curso denominado "Energética", realizado em maio/ junho 1996, "Calunga" resumiu a sua biografia dizendo-se descendente de escravo no Brasil. Segundo "seu relato" foi a avó quem o iniciou nas "artes da feitiçaria". Ele "praticou o mal" durante anos, até que uma "visão" do seu orixá o levou a usar os seus conhecimentos para a cura. Sofreu muito no final da vida e nos primeiros tempos da vida pósmorte em função do mal praticado. Seu trabalho atual, junto a Luiz Gasparetto, é tido, portanto, como parte do processo de expiação de seu karma.

Bibliografia

ALMEIDA, Ronaldo. “A guerra das possessões", em ORO, Pedro; CORTEN, André e DOZON, J. P. (orgs.). Igreja Universal do Reino de Deus. São Paulo, Paulinas, 2003. 
ALMEIDA, Ronaldo. Dinâmica religiosa na metrópole paulistana. São Paulo, Centro de Estudos da Metrópole. www.cebrap.org.br, 2004.

AUBRÉE, Marion e LAPLANTINE, François. La table, le livre et les esprits. Paris, Editions JCLattes, 1990.

BARBOSA, Elias. No mundo de Chico Xavier. São Paulo, IDE, 1992.

BASTIDE, Roger. As religiões africanas no Brasil. São Paulo, Pioneira, 1960.

BIRMAN, Patrícia. "Destino dos homens e sacrifício animal: comparando carismáticos e pentecostais". Comunicações do Iser, n. 45, 1994a, pp. 35-43

"Cultos de possessão e pentecostalismo no Brasil: passagens". Religião e Sociedade 17-1/2, 1994b, pp. 90-108.

Fazer gênero criando estilos. Rio de Janeiro, Relume Dumara/ Eduerj, 1995.

CAMARGO, Cândido P. Kardecismo e Umbanda. São Paulo, Pioneira, 1961.

CARNEIRO, L. P. e SOARES, L. E. "Religião, estrutura social e comportamento político", em BINGEMER, Maria Clara (org.). O impacto da modernidade sobre a religião. São Paulo, Loyola, 1995.

CAVALCANTI, Maria Laura Viveiros de. O mundo invisivel. Cosmologia, sistema ritual e noção de pessoa no Espiritismo. Rio de Janeiro, Zahar, 1983.

CERIS. Desafios do Catolicismo na cidade. São Paulo, Paulus, 2002.

CERTEAU, Michel de. "Uma variante: a edificação hagiográfica", em $A$ escrita da História. Rio de Janeiro, Forense, 1982.

D'ANDREA, Antony. O self perfeito e a nova era. Individualismo e reflexividade em religiosidades pós-tradicionais. São Paulo, Loyola, 2000.

DANTAS, Beatriz G. Vovó nagô e papai branco. Rio de Janeiro, Graal, 1988.

FERNANDES, Rubem C. et allii. Novo nascimento. Os evangélicos em casa, na igreja e na política. Rio de Janeiro, Mauad, 1998.

GAMA, Ramiro. Lindos casos de Chico Xavier. São Paulo, LAKE, 1995.

GASPARETTO, Luiz A. Faça dar certo. São Paulo, Espaço Vida e Consciência, s/d.

GIUMBELLI, Emerson. “O 'baixo Espiritismo' e a história dos cultos mediúnicos”, em Horizontes Antropológicos, vol. 9, n. 19, 2003, pp. 247-281.

MACHADO, Ubiratan. Chico Xavier - uma vida de amor. São Paulo, IDE, 1992.

MAGGIE, Yvonne. Medo de feitiço: relações entre a magia e o poder no Brasil. Rio de Janeiro, Arquivo Nacional, 1992.

MARIZ, Cecilia e MACHADO, Maria das Dores. "Sincretismo e trânsito religioso: comparando carismáticos e pentecostais”. Comunicações do ISER n. 45, 1994, pp. 24-34.

NOBRE, Marlene R. S. Lições de sabedoria. Chico Xavier nos 22 anos da Folha Espirita. São Paulo, Editora Jornalística Fé, 1996.

ORTIZ, Renato. A morte branca do feiticeiro negro. São Paulo, Brasiliense, [1978] 1991.

PRANDI, Reginaldo. Herdeiras do Axé. São Paulo, Hucitec, 1996.

RODRIGUES, Arackci e MUEL-DREYFUS, Francine. "Reencarnações. Notas de pesquisa sobre uma seita espírita em Brasília". Revista Brasileira de Ciências Sociais no 31, 1987 pp. 102-1212. 
SANCHIS, Pierre. "O repto pentecostal à cultura brasileira". Revista de Antropologia n. 37,1994 , pp. 145-181.

"Religiões, religião... Alguns problemas do sincretismo no campo religioso brasileiro", em SANCHIS, P. (org.). Fiéis de Cidadãos. Percursos de Sincretismo no Brasil. Rio de Janeiro, Eduerj, 2001.

SOUTO MAIOR, Marcel. As vidas de Chico Xavier. Rio de Janeiro, Rocco, 1995.

STOLL, Sandra J. Entre dois mundos: o Espiritismo da França e no Brasil. Tese de Doutorado, São Paulo, USP, 1999.

TAVARES, Clóvis. Trinta anos com Chico Xavier. São Paulo, IDE, [1967] 1991.

RESUMO - A BIOGRAFIA de dois médiuns brasileiros - Chico Xavier e Luiz Antonio Gasparetto -, constitui o objeto de reflexão deste artigo, que tem como propósito rever as relações construídas pelo espiritismo no campo religioso brasileiro, salientando, em especial, os diálogos estabelecidos com a religião hegemônica no país, o catolicismo e, mais recentemente, com o universo da chamada "Nova Era". Na trajetória dos personagens em questão, o catolicismo ocupa lugar central: no caso de Chico Xavier como matriz de reinterpretação da doutrina espírita; no caso de Luiz Antonio Gasparetto, como alvo de crítica. Essas duas biografias caracterizam, portanto, momentos distintos da história do espiritismo no Brasil. Ao mesmo tempo, a convivência desses dois modelos evidencia modos concorrentes de sua expressão contemporânea no país.

ABSTRACT - THE BIOGRAPHY of two Brazilian psychics - Spiritist channelers Chico Xavier and Luiz Antonio Gasparetto - is this essay's object of thought, a review of the relationships created by Spiritism in the Brazilian religious milieu, stressing in particular the dialogue with the country's hegemonic religion, Catholicism, and, more recently, with the universe of the so-called New Age. In the life history of the two mediums, Catholicism plays a central role: for Chico Xavier as a matrix to reinterpret the Spiritist doctrine; for Luiz Antonio Gasparetto, as an object of criticism. The two biographies, therefore, characterize distinct moments in the history of Spiritism in Brazil. At the same time, the simultaneous existence of both models evinces competing modes of their contemporary expression in Brazil.

Sandra Jacqueline Stollé professora do Departamento de Antropologia da Universidade Federal do Paraná (UFPR), com doutorado em Antropologia pela Universidade de São Paulo (USP). É membro do NAU (Núcleo de Antropologia Urbana da USP) e coordenadora do Nuarp (Núcleo de Arte, Ritual e Performance da UFPR). É autora de Espiritismo à brasileira (Edusp/Orion, 2003).

Texto recebido e aceito para publicação em 20 de setembro de 2004. 